\title{
Article
}

\section{The transition of adolescents with juvenile idiopathic arthritis or epilepsy from paediatric health-care services to adult health-care services: A scoping review of the literature and a synthesis of the evidence}

Burke, Lauren, Kirkham, Jamie, Arnott, Janine, Gray, Victoria, Peak, Matthew and Beresford, Michael W

Available at http://clok.uclan.ac.uk/21465/

Burke, Lauren, Kirkham, Jamie, Arnott, Janine ORCID: 0000-0001-8512-7550, Gray, Victoria, Peak, Matthew and Beresford, Michael W (2018) The transition of adolescents with juvenile idiopathic arthritis or epilepsy from paediatric health-care services to adult health-care services: A scoping review of the literature and a synthesis of the evidence. Journal of Child Health Care, 22 (3). pp. 332-358. ISSN 1367-4935

It is advisable to refer to the publisher's version if you intend to cite from the work. http://dx.doi.org/10.1177/1367493517753330

For more information about UCLan's research in this area go to and search for < name of research Group >.

For information about Research generally at UCLan please go to http://www.uclan.ac.uk/research/

All outputs in CLoK are protected by Intellectual Property Rights law, including Copyright law. Copyright, IPR and Moral Rights for the works on this site are retained by the individual authors and/or other copyright owners. Terms and conditions for use of this material are defined in the policies page. 


\title{
Scoping Review
}

\section{The Transition of Adolescents with Juvenile Idiopathic Arthritis (JIA) or Epilepsy from Paediatric Health Care Services to Adult Health Care Services: A Scoping Review of the Literature and a Synthesis of the Evidence}

\author{
Lauren Burke \\ Institute of Translational Medicine, University of Liverpool, United Kingdom \\ Jamie Kirkham \\ Institute of Translational Medicine, University of Liverpool, United Kingdom \\ Janine Arnott \\ School of Nursing, University of Central Lancashire, United Kingdom \\ Victoria Gray \\ Alder Hey Children's NHS Foundation Trust, United Kingdom \\ *Matthew Peak \\ Alder Hey Children's NHS Foundation Trust, United Kingdom \\ *Michael W Beresford \\ Institute of Translational Medicine, University of Liverpool, United Kingdom \\ Alder Hey Children's NHS Foundation Trust, United Kingdom \\ *Joint senior authors
}

\section{Abstract}

Young people with long-term health conditions (LTCS) can face challenges when making the transition to adult health services. This paper sought to identify studies that assess and explore transitional care for young people with LTCs. Two conditions were used as exemplars: juvenile idiopathic arthritis (JIA) and epilepsy. A scoping review of the literature was conducted by using search terms to search for papers in English between 2001 and 2016 concerning transitional care on four databases. Qualitative papers were reviewed and synthesized using thematic analysis. Quantitative papers using health outcomes were also synthesized. Twenty-eight papers were selected for review. Despite the wealth of literature concerning aspects of transitional care that are key to a successful transition for young people with JIA or epilepsy, 
there is a paucity of outcomes that define 'successful' transition and consequently a lack of reliable research evaluating the effectiveness of transitional care interventions to support young people moving to adult health services.

Key words; Transition; Transitional care; JIA; Epilepsy; Adolescence

This study is part-funded by the National Institute for Health Research Collaboration for Leadership in Applied Health Research and Care North West Coast (NIHR CLAHRC NWC).

The views expressed are those of the authors and not necessarily those of the NHS, NIHR or Department of Health. 


\section{Introduction}

An increasing number of children with long-term chronic health conditions are now surviving into adulthood (Perrin et al 2007; 2014). due to advances of treatments and technologies that are increasing survival rates (Kennedy et al., 2007). This advance has highlighted the importance of the transition to adult care process and the organization of transitional care (Crowley et al., 2011; Suris and Akre, 2015). Effective transition has been recognized as an essential component of quality health-care provision and has furthermore been identified as a critical area needing improvement (Department of Health \& Department for Children Schools and Families, 2007, 2008; Department of Health \& Department for Education and Skills, 2004, 2006; McDonagh, Shaw, et al., 2006; NHS Children's Review, 2010; Royal College of Paediatrics and Child Health, 2003).

Recent policies within the United Kingdom have stipulated the need to develop robust and effective interventions to support transitional care that will consequentially prevent a decline in health for young people (Annual report of the Chief Medical Officer: Our children deserve better: Prevention pays, 2012; Transition: moving on well, DoH, 2008; National Service Framework for Children, Young People and Maternity Services, 2004; Transition: getting it right for young people, DoH, 2006; 'From the Pond to the Sea'; Care Quality Commission, 2014). A recent Cochrane review identified a limited range of interventions developed to facilitate transition and concluded that further research is needed that rigorously evaluates models of transitional care that use longer follow-ups and use clinical outcomes (Campbell et al., 2016). These policy documents, alongside the recently published National Institute for Health and Care Excellence guidelines (2016), emphasize the barriers to effective transition, such as reduction of services, lack of streamlined funding, decline in support during and after transition, lack of continuity in transition pathways, and the absence of the views of young people in contributing to the development of transition services. 
It is important to highlight the vulnerability that adolescents with chronic health need experience during transition; adolescence can be a particularly turbulent time in which educational, employment, psychosocial, and vocational needs should be supported. For adolescents with long-term conditions, this unsettling time can mean increased stress as a consequence of managing their health condition. Rosen et al. (2003) recognizes the need for a multidimensional and holistic transition programme that goes beyond delivering medical care and supports the adolescent's psychosocial, educational, and vocational needs.

Research has shown that poor transitional care, lack of follow-up post-transition, and failed adjustment to adult care lead to fewer attended doctor appointments and a deterioration in health (Kennedy et al., 2007; Singh et al., 2010).

To date, there has been a limited amount of transitional care programmes that have been evaluated using health-related outcomes (Crowley et al2011). The need for transitional care for patients with rheumatological and neurological conditions is well-established (Department of Health \& Department for Education and Skills, 2006). There is no current consensus in the transition literature regarding how best to evaluate transition services and how to recognize successful transition. Previous studies have developed and employed outcome measures for transition, for example, outcomes that measure satisfaction and continuity of care (e.g. Shaw et al., 2006; Tysbina et al., 2012). However, the question remains as to which measures have a robust rationale and evidence-based construct for their use. The absence of informed stakeholder perspectives on which outcomes to utilize, as well as the diverse range of irrelevant outcomes currently being used, has consequently led to the lack of a consensus-driven approach in evaluating the effectiveness of transitional care interventions. 
To review and summarize, the transitional care literature uses two long-term health conditions (LTCs): epilepsy and juvenile idiopathic arthritis (JIA). JIA and epilepsy are used as two exemplar conditions to identify outcomes that are relevant in the assessment of interventions intended to improve transitional care, although it is envisaged that the results will have potential to be applicable more generally across different long-term conditions and health specialties. JIA and epilepsy were chosen as two exemplar conditions as we envision our research will be implemented in the rheumatology and neurology services at Alder Hey Children's Hospital and partnering adult hospitals. It is important to note that when reviewing the literature, we aimed to collate experiences of transitional care, outcomes that relate to the 'processes' of transitional care as well as health-related 'outcomes' that have previously been used to measure the effectiveness of transitional care.

\section{Methods}

\section{Search criteria}

We conducted a review of the literature using key words and subject headings on four databases (see appendix A): EMBASE, Scopus, PubMed and Cochrane Register of Controlled Trials. The strategy combined words associated with three categories: the population (adolescent, teen, young adult,), the subject of interest (transition, transfer, transition to adult care), and the chronic conditions of interest (JIA and epilepsy). The search was completed on 15 February 2016.

Study titles and abstracts were screened by one reviewer (LB) and on discussion with a second reviewer $(J A)$, papers were rejected if they did not meet the inclusion criteria. Full text papers were obtained for remaining papers and these were read thoroughly to 
determine eligibility. Authorship, year of publication, and results were extracted from all papers. For papers that included a transitional care programme or intervention, rationale for their use of programme and outcomes such a health-related outcomes used to measure the programme's effectiveness were also extracted. Results from qualitative papers were extracted verbatim.

\section{Eligibility criteria}

Studies were included if their primary research aim concerned patients transitioning from paediatric to adult care, as well as studies that include the patients', parents, carers and health care professionals. Studies related to health care transitions of young people with other chronic conditions were identified. Articles that did not focus on JIA or Epilepsy exclusively but focussed on other conditions in addition to JIA or Epilepsy were included in the review to augment the limited literature focussing on exclusively JIA or Epilepsy patients transitioning.

Articles with qualitative or quantitative methodologies were eligible for review. Studies were eligible for inclusion if they reported i) 'outcomes' of the transition process during and after transition ii) health related outcomes iii) experiences of transition. All study designs were included. Reference lists from all articles found through the initial database search of studies were reviewed to identify key articles not found in the original search. Studies published between January 1, 2001 and February 15, 2016 with an English language title and abstract were included. 
Qualitative literature concerning experiences and processes of transitional care were integrated using thematic analysis (Braun \& Clarke, 2006). This method was used to permit a transparent approach to achieving data-driven themes that are interpreted from an occurring phenomenon. NVivo 9 (QSR-International) was used to deductively code processes of transitional care verbatim from the data set independently by two authors (LB, JA). Codes and themes were discussed with four other authors (VG, MP, MWB, JK). Any disagreement was resolved through discussion. Cohen's Kappa coefficient was used to determine the level of agreement between researchers when deriving themes; a kappa score of $>0.61$ indicated a good level of agreement on themes (Cohen, 1960).

\section{Synthesis of the quantitative literature}

Quantitative articles concerning processes of transitional care as well as outcomes of transition were grouped by methodology used; primarily by design, for example; audit, questionnaire, health-related outcomes.

\section{Results}

\section{Systematic Search}

5094 articles were retrieved for assessment against the inclusion criteria with thirty-one papers matching the criteria for inclusion, this process is summarised in figure 1. Eight papers were qualitative and explored experiences of patients, parents and carersundergoing 
transition as well as the health professionals involved in transitional care. Twenty-three quantitative papers assessed existing or newly-implemented transitional care services using surveys, questionnaires and audit measures.

Fig. 1. Flow chart for scoping review procedure.

Fig. 1. Flow chart for scoping review procedure.

Results from database search. Databases searched: SCOPUS, EMBASE, PUBMED and CENTRAL $(\mathrm{n}=5094)$

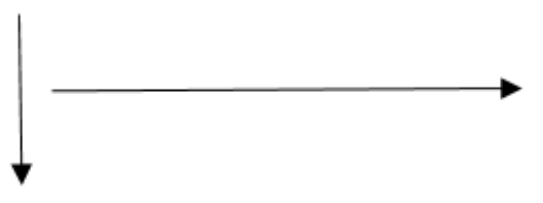

Excluded on basis of titles and abstracts (did not meet inclusion criteria) ( $n=5056$ )

Retrieved for more detailed evaluation $(n=38)$

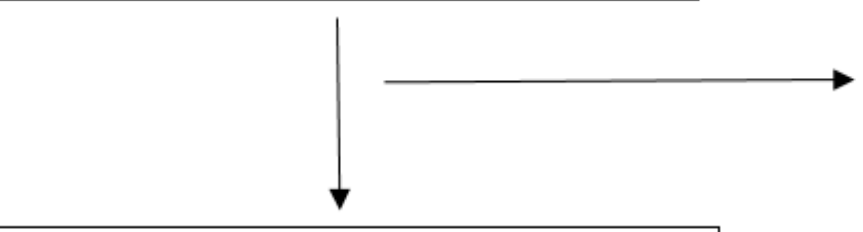

Excluded (did not meet inclusion criteria; paper access, PhD publication, language access, articles not including JIA or Epilepsy) ( $n=7)$

Detailed review $(n=31)$

Qualitative $(n=8)$, Quantitative $(n=23)$ 


\section{Synthesis of qualitative literature}

Eight qualitative studies were identified to review; three studies included young people with JIA and their families, three included patients and their families with a mixture of long-term conditions including JIA and two included participants with Epilepsy. Qualitative study characteristics can be found in table 1 .

Table 1. Characteristics of included qualitative studies.

\begin{tabular}{|l|l|l|l|}
\hline $\begin{array}{l}\text { Author, year and } \\
\text { country }\end{array}$ & Condition explored & Rationale & Participants \\
\hline $\begin{array}{l}\text { Shaw, Southwood } \\
\text { (2004) }\end{array}$ & JIA & $\begin{array}{l}\text { Examine the transitional needs of } \\
\text { young people with JIA }\end{array}$ & $\begin{array}{l}\text { Adolescents (12-18 yrs) } \\
n=12\end{array}$ \\
& & & $\begin{array}{l}\text { Parents of adolescents } \\
n=14\end{array}$ \\
& & $\begin{array}{l}\text { Young adults (19-30 yrs) } \\
n=18\end{array}$ \\
\hline $\begin{array}{l}\text { Tuchman, Slap \& } \\
\text { Britto (2008) }\end{array}$ & JIA \& others & $\begin{array}{l}\text { Assess expectations and concerns } \\
\text { from young people with a chronic } \\
\text { illness during their transition }\end{array}$ & $\begin{array}{l}\text { Adolescents (15-21 yrs) } \\
n=22\end{array}$ \\
USA & Parents of young adults \\
\hline $\begin{array}{l}\text { Van Staa, Jedeloo, } \\
\text { Meetern \& Latours } \\
\text { (2011) }\end{array}$ & JIA \& others & $\begin{array}{l}\text { Explore experiences of young } \\
\text { people transferring to adult care } \\
\text { and identify recommendations }\end{array}$ & $\begin{array}{l}\text { Young adults (15-22 yrs) } \\
n=24\end{array}$ \\
\hline
\end{tabular}




\begin{tabular}{|c|c|c|c|}
\hline The Netherlands; & & & $\begin{array}{l}\text { Parents } n=24 \\
\text { Healthcare professionals } \\
n=17\end{array}$ \\
\hline $\begin{array}{l}\text { Hilderson et al } \\
\text { (2013) } \\
\text { Belgium }\end{array}$ & $J I A$ & $\begin{array}{l}\text { Assess the differences between } \\
\text { experiences and expectations of } \\
\text { transitional care for young adults } \\
\text { with JIA }\end{array}$ & $\begin{array}{l}\text { Young adults (18-30 yrs) } \\
n=11\end{array}$ \\
\hline $\begin{array}{l}\text { Lewis \& Noyes } \\
\text { (2013) } \\
\text { UK }\end{array}$ & Epilepsy & $\begin{array}{l}\text { To explore information, } \\
\text { communication and experiences of } \\
\text { knowledge for young people } \\
\text { transitioning in a clinical setting }\end{array}$ & $\begin{array}{l}\text { Young people (13-19 } \\
\text { yrs) } n=30 \\
\text { Parents } n=28\end{array}$ \\
\hline $\begin{array}{l}\text { Schultz (2013) } \\
\text { USA }\end{array}$ & Epilepsy & $\begin{array}{l}\text { Explore the processes that parents } \\
\text { of children with Epilepsy undergo } \\
\text { when they transfer to adult health } \\
\text { care services }\end{array}$ & $\begin{array}{l}\text { Parents of young adults } \\
(>18) \text { with Epilepsy who } \\
\text { have transferred to } \\
\text { adult services } n=7\end{array}$ \\
\hline $\begin{array}{l}\text { Cruikshank et al } \\
(2015) \\
\text { UK }\end{array}$ & JIA & $\begin{array}{l}\text { Explore the roles of health } \\
\text { professionals, young adults with JIA } \\
\text { and their families in the transition } \\
\text { process }\end{array}$ & $\begin{array}{l}\text { Young people (12-17 } \\
\text { yrs) } n=8 \\
\text { Parents } n=21 \\
\text { Health professionals } \\
n=41\end{array}$ \\
\hline $\begin{array}{l}\text { Howland \& Fisher } \\
\text { (2015) } \\
\text { UK }\end{array}$ & JIA & $\begin{array}{l}\text { To establish the needs of young } \\
\text { people with JIA transitioning to } \\
\text { adult care and assess gaps in care }\end{array}$ & $\begin{array}{l}\begin{array}{l}\text { Young adults (16-18 yrs) } \\
n=6\end{array} \\
\text { Parents } n=5 \\
\text { Health professionals } \\
n=7\end{array}$ \\
\hline
\end{tabular}

A significant proportion of the qualitative findings relate to 'processes' of transitional care.

These include barriers and facilitators to successful transitions, as well as expectations and experiences from the viewpoint of young adults, parents, carers and health professionals. Through analysing the literature, we identified three main themes; 'Capability' of the young 
adult, 'Communication' (between health professionals and between the young

adult/parent/carer and health professional) and 'Continuity' of care between services.

Themes and sub-themes that emerged are represented in figure 2.

Fig 2. Diagram depicting emerged main themes and sub-themes from the review of qualitative literature.

\section{COMMUNICATION}

-Accessible information for young people transitioning and their parents \& carers.

-Support and encourage patients to communicate and express their needs.

- Efficient and thorough communication between health professionals.

- Honest, open and age-appropriate communication between health professional and patient.

\section{CONTINUITY}

- Early transition planning.

- Coordination between services (e.g. passing of patient information).

- Joint transition plan in place between paediatric and adult services.

-Joint transition clinic to be held with paediatric and adult services.

\section{CAPABILITY}

-Independence of the young person.

- Readiness to transition.

-Active preparation of the young person to transfer (e.g. opportunity to familiarise with the adult clinic).

- Confidence to manage their condition (e.g. has the young person's education, psychosocial and vocational needs been met?). 


\section{Capability}

There was consensus among the qualitative literature that by enhancing the capability of a young adult, you can increase their knowledge, self-management of their condition, and foster independence; these are seen as key facilitators of a successful transfer to adult health care (Cruikshank et al., 2016; Hilderson et al., 2013; Howland and Fisher, 2015; Lewis and Noyes, 2013; Schultz, 2013; Shaw et al., 2004; Tuchman et al., 2008; Van Staa et al., 2011). However, it is evident that preparing the young adult in managing their own health and increasing their self-efficacy is not always pursued (Cruikshank et al., 2016) with health professionals admitting that not all young people are prepared and enter adult services ' with nothing'. Similarly, young people report being ill-prepared, with transition happening 'too suddenly' (Hilderson et al., 2013; Shaw et al., 2004) and that transitioning to adult services is envisioned as a 'deadline' (Tuchman et al., 2008).

The majority of the literature illustrates young peoples' expectations and experiences (as well as families and health professionals' experiences and expectations) regarding a young person's capability during transition, for example, the chance to familiarize with the adult health-care service and professionals before transfer. In addition to having the opportunity to attend a joint clinic in which both paediatric and adult health professionals participate (Cruikshank et al., 2016; Hilderson et al., 2013; Howland and Fisher, 2015; Lewis and Noyes, 2013; Tuchman et al., 2008; Van Staa et al., 2011). Schultz (2013) found that parents had felt fear and uncertainty regarding where their child will receive health care after they leave paediatric services and they saw themselves as having the role of the 'protector' that took charge. Likewise, Lewis and Noyes (2013) interviewed young people with epilepsy and their 
parents and found that parents felt they needed to be educated and empowered to be advocates for their children's health during transition. Despite some young adults reporting that parent involvement was beneficial to their transfer (Hilderson, 2013; Tuchman et al., 2008), promoting a young adult's independence to depend less on their parents or carers was also seen as significant to increasing the young person's capability to transfer to adult services (Shaw et al., 2004; Van Staa et al., 2011). Moreover, some young people reported that they felt most empowered when they broke away from their parents to see health professionals by themselves (Tuchman et al., 2008).

Although fostering a young person's independence is considered important during transfer throughout the literature, health professionals have acknowledged that paediatric services can be overprotective and there is less encouragement of independence compared to adult services with young people reporting that they feel 'mothered' (Hilderson, 2015). For young people, the need for being prepared for the differences between services, being allowed to make informed choices in their own care (Van Staa et al., 2011), having the opportunity to familiarize with the adult care setting (Howland and Fisher, 2015) and having the option to be seen alone in paediatric care (Shaw et al., 2004) is seen as valuable stages to increasing independence, preparedness and consequently increasing their capability to transfer to adult care comfortably.

\section{Communication}

According to the qualitative literature, one enabler of a successful transition was dependent on the communication they receive from their health professional. Cruikshank et al. (2016) found that individual characteristics of health professionals that have strong interpersonal relationships with their patients are strong advocates for young people. Similarly, a focus group with young people with JIA and their parents found that interpersonal relationships with their health professional increased the trust they had for them. Shaw et al. (2004) found that young people wanted communication from their health professional that was realistic, jargon-free and honest. Throughout the literature, it is apparent that some young people and their parents/carers do not receive the right information (Lewis and Noyes, 2013; 
Shaw et al., 2004; Van Staa et al., 2011), and there was a consensus among parents interviewed that parent support groups were most beneficial for obtaining information. In a study with young adults with epilepsy and their parents, it was found that young people did not receive the right information at the right frequency or at the right time during their teenage years. Furthermore, information was not gender-specific (Lewis and Noyes, 2013). Although discussing medical information is considered an important aspect in an appointment, young people with JIA found that discussions regarding daily life with JIA and emotional and developmental topics were factors just as important to them (Howland and Fisher, 2015). The need for lifestyle advice and management was also seen across the epilepsy population in the literature (Lewis and Noyes, 2013).

\section{Continuity}

A prominent theme across the qualitative literature was the continuity of care that is provided between paediatric and adult health-care services. Cruikshank et al. (2016) found that health professionals acknowledged there was not one clear pathway for transition and there were workforce shortfalls in their services which affected the provision of transitional care. Furthermore, health professionals noted the differences between paediatric and adult health services: variances in priorities, differences in service infrastructure, standards of care and historic encounters. This was further echoed by professionals who stated there were differences in treatment protocols and working methods between hospitals (Van Staa et al., 2011).

Young people rated having continuity in who they see at appointments as important during transition (Hilderson et al., 2013); however, Shaw et al. (2004) found that young adults felt that their trust with health professionals eroded when there were strangers in the room at their appointments. Echoing this, health professionals acknowledged that most professionals did not know each other between paediatric and adult services, despite the facilities being in the same premises (Van Staa et al., 2011). Of those young people that were interviewed within the qualitative literature, they reported feeling a lack of coordination between services with no team approach (Van Staa et al., 2011), reported feeling frustrated at having 
to go through their medical history repeatedly when they arrive at adult services (Tuchman et al., 2008) and felt that there was poor coordination between services that had led to delays in transfer, cancelled appointments and discontinuation of care (Shaw et al., 2004).

\section{Synthesis of quantitative transition literature}

Articles were grouped by methodology used, primarily by design, for example, audit, questionnaire and health-related outcomes. This information was compiled in a table format to summarize methodologies used in the articles (see Table 2). Although this review does not focus on intervention type, a brief description of each study can be found in this table to provide context for each study. Of the small number of transition studies that use a quantitative design, the methodologies used were varied.

Table 2. Characteristics of included quantitative studies 


\begin{tabular}{|c|c|c|c|c|c|}
\hline $\begin{array}{l}\text { Author, year } \\
\text { and location }\end{array}$ & Condition & Intervention & Rationale & Outcome measures used & Results \\
\hline \multicolumn{6}{|c|}{ Studies using outcome measures to assess service quality improvement } \\
\hline $\begin{array}{l}\text { Disabato et al } \\
(2015) \\
\text { USA }\end{array}$ & $\begin{array}{l}\text { Epilepsy \& } \\
\text { other } \\
\text { neurological } \\
\text { conditions }\end{array}$ & $\begin{array}{l}\text { Service quality } \\
\text { improvement } \\
\text { approach }\end{array}$ & $\begin{array}{l}\text { Enhance smooth transfer of } \\
\text { patient documents } \\
\text { Increase patient self- } \\
\text { management skills } \\
\text { Enhance smooth transfer of } \\
\text { young adult to adult care via } \\
\text { communicative } \\
\text { improvements } \\
\text { Assess the teams transition } \\
\text { knowledge, comfort and } \\
\text { satisfaction }\end{array}$ & $\begin{array}{l}\text { Time from referral to } 1^{\text {st }} \\
\text { adult appointment (chart } \\
\text { review) } \\
\text { Patient Activation Measure } \\
\text { (PAM) (V)* } \\
\text { Audit report (electronic } \\
\text { medical records) } \\
\text { Satisfaction survey (NV) }\end{array}$ & $\begin{array}{l}\text { Significant decrease in time to transition } \\
(p=0.004),[206 \text { days in } 2010 \text { to } 62 \text { days in } \\
2011] \\
\text { No change in the } 44 \% \text { of patients who } \\
\text { completed both pre and post PAM } \\
\text { surveys. } \\
\text { Significant increase of the number of } \\
\text { referrals ( } p=0.006 \text { ), [ } 5.8 \% \text { at baseline, } \\
27.5 \% \text { at } 8 \text { months] } \\
\text { Improvement in mean scores for six } \\
\text { knowledge skills items (mean } 2.75 \text { to } \\
3.08 \text { ); results not statistically } \\
\text { significant }\end{array}$ \\
\hline \multicolumn{6}{|c|}{ Studies using outcome measures to assess patient \& parent aspects } \\
\hline $\begin{array}{l}\text { Stringer (2015) } \\
\text { Canada }\end{array}$ & JIA \& others & $\begin{array}{l}\text { Transition clinic } \\
\text { with paediatric } \\
\text { and adult } \\
\text { rheumatologists } \\
\text { present. }\end{array}$ & $\begin{array}{l}\text { Evaluate the effect of a } \\
\text { transition clinic on patient } \\
\text { daily functioning, education, } \\
\text { satisfaction and rate of } \\
\text { follow-up in the adult clinic }\end{array}$ & $\begin{array}{l}\text { Satisfaction with transition } \\
\text { clinic using a visual analogue } \\
\text { scale (VAS) (NV) }\end{array}$ & $\begin{array}{l}\text { There was overall satisfaction with } \\
\text { transition clinic (mean=7.3 out of } \\
10 \mathrm{~cm} \text { on a VAS). } \\
\text { However, variation in how well items } \\
\text { were addressed ( } 4.3 \text { to } 7.6 \text { on a } 10 \mathrm{~cm} \\
\text { VAS). These items included } \\
\text { information regarding sexual health, }\end{array}$ \\
\hline
\end{tabular}




\begin{tabular}{|c|c|c|c|c|c|}
\hline & & & & $\begin{array}{l}\text { Quality of life (Medical } \\
\text { Outcomes Study-SF-36) (V) } \\
\text { Health assessment } \\
\text { (Stanford Health } \\
\text { Assessment Questionnaire) } \\
\text { (V) }\end{array}$ & $\begin{array}{l}\text { alcohol use, drug use and learning } \\
\text { about new developments relating to } \\
\text { their condition } \\
\text { Impairments in most domains of } \\
\text { quality of life (physical function, bodily } \\
\text { pain, social functioning and mental } \\
\text { health). Approximately one quarter of } \\
\text { respondents scored greater than } 2 \\
\text { standard deviations below the mean in } \\
5 \text { out of } 8 \text { domains on theSF-36 } \\
\text { Median score on the HAQ index (range } \\
\text { from } 0 \text { to } 1.5 \text { ) was } 0.125 \text { representing } \\
\text { mild disability }\end{array}$ \\
\hline $\begin{array}{l}\text { McDonagh, } \\
\text { Shaw } \\
\text { \&Southwood } \\
\text { (2006) } \\
\text { UK }\end{array}$ & JIA & $\begin{array}{l}\text { Transitional care } \\
\text { programme that } \\
\text { was } \\
\text { individualised } \\
\text { that had a range } \\
\text { of components } \\
\text { (local } \\
\text { coordinator, } \\
\text { transition policy } \\
\text { template, } \\
\text { individual } \\
\text { transition plan } \\
\text { templates) }\end{array}$ & $\begin{array}{l}\text { To determine whether there } \\
\text { was an improvement in } \\
\text { quality of life due to the } \\
\text { transitional care programme }\end{array}$ & $\begin{array}{l}\text { HRQOL using Juvenile } \\
\text { Arthritis Quality of life } \\
\text { Questionnaire (JAQQ) (V) } \\
\text { Arthritis-related knowledge } \\
\text { (NV) } \\
\text { Satisfaction with } \\
\text { rheumatology care (Mind } \\
\text { the Gap) (V) } \\
\text { Independent health } \\
\text { behaviours (NV) }\end{array}$ & $\begin{array}{l}\text { Improvements in adolescent HRQL at } \\
6 \text { and } 12 \text { month follow-ups compared } \\
\text { to baseline ( } p<0.001, p<0.01) \\
\text { Improvements in parent-proxy HRQL } \\
\text { at } 6 \text { and } 12 \text { month follow-ups } \\
\text { compared to baseline }(p<0.01 \text {, } \\
p<0.001) \\
\text { Improvement in adolescent } \\
\text { knowledge at the } 6 \text { and } 12 \text { month } \\
\text { follow-up time points compared to } \\
\text { baselines ( } p<0.001, p<0.001 \text { ) } \\
\text { Improvement in parent knowledge at } \\
\text { the } 6 \text { and } 12 \text { month follow-up time }\end{array}$ \\
\hline
\end{tabular}




\begin{tabular}{|c|c|c|c|c|c|}
\hline & & & & $\begin{array}{l}\text { Pre-vocational experience } \\
\text { (NV) } \\
\text { Clinical data (JIA related) } \\
\text { Childhood health } \\
\text { Assessment Questionnaire } \\
\text { (CHAQ) (V) } \\
\text { Core Outcome Set (COS) of } \\
\text { JIA variables (Giannini et al) }\end{array}$ & $\begin{array}{l}\text { points compared to baseline }(p< \\
0.001, p<0.001) \\
\text { Improvement in adolescent } \\
\text { satisfaction at the } 6 \text { and } 12 \text { month } \\
\text { follow-up time points compared to } \\
\text { baseline ( } p<0.01, p<0.01 \text { ) } \\
\text { Improvements in parent satisfaction at } \\
\text { the } 6 \text { and } 12 \text { month follow-up time } \\
\text { points compared to baseline ( } p< \\
0.001, p<0.001 \text { ) } \\
\text { No significant change in self- } \\
\text { medication or independent } \\
\text { consultations at any time point } \\
\text { Significant improvements were } \\
\text { reported for adolescent work } \\
\text { experience at } 6 \text { month and } 12 \text { month } \\
\text { time points ( } p<0.001, p<0.001 \text { ) }\end{array}$ \\
\hline $\begin{array}{l}\text { Shaw, } \\
\text { Southwood \& } \\
\text { McDonagh } \\
\text { (2006) } \\
\text { JIA } \\
\text { UK }\end{array}$ & JIA & $\begin{array}{l}\text { A transitional } \\
\text { care programme } \\
\text { for adolescents } \\
\text { with JIA at } 10 \\
\text { paediatric } \\
\text { rheumatology } \\
\text { centres. } \\
\text { (In conjunction } \\
\text { with the above } \\
\text { study) }\end{array}$ & $\begin{array}{l}\text { Evaluate patient and parent's } \\
\text { satisfaction of a transitional } \\
\text { care programme }\end{array}$ & $\begin{array}{l}\text { Satisfaction with } \\
\text { rheumatology care } \\
\text { (Mind the Gap) (V) }\end{array}$ & $\begin{array}{l}\text { Adolescent and their parents rated } \\
\text { provider characteristics and } \\
\text { coordination of care more important } \\
\text { than physical environment or process } \\
\text { issues aspects } \\
\text { Low scores were associated with the } \\
\text { hospital/clinic environment. } \\
\text { Parents have significantly ( } p<0.001 \text { ) } \\
\text { higher expectations of best practice } \\
\text { for } 77 \% \text { of the items when compared } \\
\text { with adolescents }\end{array}$ \\
\hline
\end{tabular}




\begin{tabular}{|c|c|c|c|c|c|}
\hline & & & & & $\begin{array}{l}\text { Overall satisfaction for both } \\
\text { adolescents and parents significantly } \\
\text { increased } 12 \text { months after entering } \\
\text { the transition programme } \\
\text { Parent satisfaction significantly } \\
\text { improved for } 70.4 \% \text { of items whilst } \\
\text { adolescent satisfaction improved for } \\
\text { only } 13.6 \% \text { of items }\end{array}$ \\
\hline $\begin{array}{l}\text { Hilderson } \\
\text { (2016) } \\
\text { Belgium }\end{array}$ & JIA & $\begin{array}{l}\text { Transition } \\
\text { programme with } \\
\text { various } \\
\text { components } \\
\text { (local } \\
\text { coordinator, } \\
\text { transition policy } \\
\text { template, } \\
\text { individual } \\
\text { transition plan } \\
\text { templates) }\end{array}$ & $\begin{array}{l}\text { To investigate the clinical } \\
\text { impact of a brief transition } \\
\text { programme }\end{array}$ & $\begin{array}{l}\text { Perceived health status } \\
\text { (Paediatric Quality of Life } \\
\text { PEDSQL) (V) } \\
\text { Medication Adherence } \\
\text { (SWISS HIV Cohort Study } \\
\text { Adherence Questionnaire } \\
\text { SHCS-AQ) (V) } \\
\text { Illness-related knowledge } \\
\text { (the Modified patient } \\
\text { knowledge Questionnaire) } \\
\text { (V) } \\
\text { Global Quality of life (linear } \\
\text { Analogue Scale) (V) } \\
\text { Fatigue (Multidimensional } \\
\text { Fatigue Inventory) (V) } \\
\text { Parenting dimensions: } \\
\text { promotion of independence }\end{array}$ & $\begin{array}{l}\text { Improved physical health status) } \\
\text { Improved psychosocial health status } \\
\text { Improved rheumatic-specific health } \\
\text { status } \\
\text { Improved QOL } \\
\text { Optimized parenting climate } \\
\text { Improvement in illness related } \\
\text { knowledge } \\
\text { Small negative effect for general } \\
\text { fatigue } \\
\text { Medium negative effect size detected } \\
\text { for medication adherence (OR = 3.00) }\end{array}$ \\
\hline
\end{tabular}




\begin{tabular}{|c|c|c|c|c|c|}
\hline & & & & $\begin{array}{l}\text { (Promotion Independence } \\
\text { Scale PI, Autonomy Support } \\
\text { Scale PVF, Parental } \\
\text { regulation scale, } \\
\text { psychological control scale } \\
\text { (NV) } \\
\text { Absence of disease activity } \\
\text { (V) } \\
\text { Functional status (Childhood } \\
\text { Assessment Questionnaire) } \\
\text { (V) }\end{array}$ & \\
\hline $\begin{array}{l}\text { Geerlings et al } \\
(2016) \\
\text { The } \\
\text { Netherlands }\end{array}$ & Epilepsy & $\begin{array}{l}\text { Transition clinic } \\
\text { is staffed by a } \\
\text { neurologists/epil } \\
\text { eptologist, } \\
\text { neuropsychologi } \\
\text { st, a social } \\
\text { worker and an } \\
\text { educational/occ } \\
\text { upational } \\
\text { counsellor }\end{array}$ & $\begin{array}{l}\text { To describe the processes } \\
\text { and outcomes of the Epilepsy } \\
\text { transition clinic in a tertiary } \\
\text { centre }\end{array}$ & $\begin{array}{l}\text { Diagnostics \& Epilepsy } \\
\text { classification (ILAE) } \\
\text { Full scale intelligence test } \\
\text { (Wechsler Intelligence Scale } \\
\text { for Children) (V) } \\
\text { Educational and vocational } \\
\text { status and living } \\
\text { arrangements (NV) } \\
\text { Special education } \\
\text { (developmental delays, } \\
\text { learning disorders etc.) (NV) } \\
\text { Social network support (NV) } \\
\text { Independence evaluated by } \\
\text { clinical neuropsychologist } \\
\text { and social worker (NV) }\end{array}$ & $\begin{array}{l}76.1 \% \text { of patients received a } \\
\text { diagnostic work-up } \\
55 \% \text { of patients had a change in anti- } \\
\text { epileptic drug prescriptions } \\
62 \% \text { received a consultation/tailored } \\
\text { advice } \\
12 \% \text { of patients had their diagnosis } \\
\text { changed } \\
16 \% \text { of patients had complete } \\
\text { remission for over one year } \\
37 \% \text { of patients were referred to adult } \\
\text { care } \\
\text { Educational ( } 21 \% \text { ) or vocational } \\
\text { assistance or training ( } 9.4 \% \text { ) that was }\end{array}$ \\
\hline
\end{tabular}




\begin{tabular}{|c|c|c|c|c|c|}
\hline & & & & $\begin{array}{l}\text { Evaluation of family support } \\
\text { by the clinical } \\
\text { neuropsychologist and } \\
\text { social worker (NV) }\end{array}$ & $\begin{array}{l}\text { appropriate for the individual's } \\
\text { capacity, were provided by the } \\
\text { educationalist/occupational counsellor } \\
\text { 14.5\% of patients had psychological } \\
\text { consultations and follow-ups } \\
26.5 \% \text { of patients required assistant by } \\
\text { the social worker to apply for suitable } \\
\text { housing or supported living } \\
\text { Improving separation from parents, } \\
\text { financial assistance or guardianship, or } \\
\text { help to improve adolescent's social } \\
\text { interaction with peers were provided } \\
\text { in } 8 \% \text { of patients, } 10 \% \text { of patients and } \\
3 \% \text { of patients respectively }\end{array}$ \\
\hline \multicolumn{6}{|c|}{ Studies using surveys and questionnaires to assess transitional care } \\
\hline Author \& Year & Condition & $\begin{array}{l}\text { Transition } \\
\text { programme in } \\
\text { place }\end{array}$ & Rationale & Outcome Measures used & Results \\
\hline $\begin{array}{l}\text { McDonagh, } \\
\text { Shaw \& } \\
\text { Southwood } \\
\text { (2006) } \\
\text { UK }\end{array}$ & $J \mid A$ & $\begin{array}{l}\text { Individualised } \\
\text { transitional care } \\
\text { programme that } \\
\text { had various } \\
\text { components; } \\
\text { local } \\
\text { coordinator, } \\
\text { transition policy } \\
\text { template, } \\
\text { individual } \\
\text { transition plan } \\
\text { templates. }\end{array}$ & $\begin{array}{l}\text { Evaluate the components of } \\
\text { the transitional care } \\
\text { programme }\end{array}$ & $\begin{array}{l}\text { Likert scale to measure } \\
\text { satisfaction with the } \\
\text { components of the } \\
\text { programme (local } \\
\text { coordinator, transition } \\
\text { policy template, individual } \\
\text { transition plan templates) } \\
\text { (NV) }\end{array}$ & $\begin{array}{l}\text { No significant differences in } \\
\text { satisfaction scores across participants } \\
\text { (patients and parents) for each } \\
\text { component of the programme at the } 6 \\
\text { month follow-up. } \\
\text { The adolescents' had a higher } \\
\text { acceptability rating for the local } \\
\text { project coordinator role compared to } \\
\text { paper based resources }(p<0.001)\end{array}$ \\
\hline
\end{tabular}




\begin{tabular}{|c|c|c|c|c|c|}
\hline $\begin{array}{l}\text { Kuchenbuch et } \\
\text { al (2013) } \\
\text { France }\end{array}$ & Epilepsy & $\begin{array}{l}\text { Existing } \\
\text { transitional care } \\
\text { practice }\end{array}$ & $\begin{array}{l}\text { Assess patients' and their } \\
\text { families' perception of } \\
\text { transition to adult healthcare }\end{array}$ & $\begin{array}{l}\text { Questionnaire to evaluate } \\
\text { medical, educational, socio- } \\
\text { professional and sexual } \\
\text { outcomes (NV) }\end{array}$ & $\begin{array}{l}61 \% \text { of patients received a transfer } \\
\text { Quality of transition preparation ( } p< \\
.001) \text {, longer duration of follow-up by } \\
\text { same child neurologist }(p<.001) \text {, the } \\
\text { availability of the child neurology staff } \\
(p<.01) \text {, a transfer into the adult } \\
\text { health care system after the age of } 18 \\
(p<.01) \text { and a stable medical } \\
\text { condition before transfer ( } p<.05) \text {, } \\
\text { were all found to be factors that } \\
\text { positively and significantly impacted } \\
\text { transfer } \\
\text { Almost all patients who experienced a } \\
\text { transfer of care reported no gap in this } \\
\text { process } \\
\text { Experiences of adult health care } \\
\text { systems were reported to be similar to } \\
\text { those of child health care systems }\end{array}$ \\
\hline $\begin{array}{l}\text { Oskoui \& } \\
\text { Wolfson (2012) } \\
\text { Canada }\end{array}$ & Neurologists & $\begin{array}{l}\text { Existing } \\
\text { transitional care } \\
\text { practice }\end{array}$ & $\begin{array}{l}\text { Assess existing practices and } \\
\text { views of paediatric and adult } \\
\text { neurologists involved in the } \\
\text { transfer of patient care }\end{array}$ & $\begin{array}{l}\text { Questionnaires including } \\
\text { statements relating to } \\
\text { barriers and facilitators to } \\
\text { transition (NV) }\end{array}$ & $\begin{array}{l}\text { 75\% of respondents report not having } \\
\text { a patient transition program/policy in } \\
\text { place } \\
\text { All paediatric neurologists report } \\
\text { sending a transfer summary and } 71 \% \\
\text { of adult neurologists reported } \\
\text { receiving one } \\
\text { Adult neurologists report that they } \\
\text { often lack critical information in the } \\
\text { transfer of medical information. }\end{array}$ \\
\hline
\end{tabular}




\begin{tabular}{|c|c|c|c|c|c|}
\hline & & & & & $\begin{array}{l}88 \% \text { of paediatric neurologists report } \\
\text { they are usually responsible for the } \\
\text { administration and coordination of } \\
\text { transition } \\
44 \% \text { of paediatric neurologists } \\
\text { reported direct communication with } \\
\text { the adult neurologist almost always or } \\
\text { sometimes when transferring a young } \\
\text { adult } \\
15 \% \text { of adult neurologists report } \\
\text { communicating directly sometimes or } \\
\text { almost always with paediatric } \\
\text { neurologists during transfer of care } \\
60 \% \text { of paediatric neurologists report } \\
\text { experiencing difficulty in finding } \\
\text { appropriate adult health care } \\
\text { providers for their patients }\end{array}$ \\
\hline $\begin{array}{l}\text { Shaw, } \\
\text { Southwood \& } \\
\text { McDonagh } \\
\text { (2004) } \\
\text { UK }\end{array}$ & JIA & N/A & $\begin{array}{l}\text { To identify the ideal } \\
\text { programme of transitional } \\
\text { care }\end{array}$ & $\begin{array}{l}\text { Two stage postal Delphi } \\
\text { with young people, their } \\
\text { parents and health } \\
\text { professionals } \\
\text { Questionnaire consisted of } \\
\text { statements that the } \\
\text { participants could agree or } \\
\text { disagree with in regard to } \\
\text { what constitutes best } \\
\text { practice }(\mathrm{NV})\end{array}$ & $\begin{array}{l}\text { Items of best transitional care agreed } \\
\text { across all groups: } \\
\text { Addressing young people' } \\
\text { psychosocial and } \\
\text { educational/vocational needs } \\
\text { Individualised approach } \\
\text { Honest explanations of the } \\
\text { adolescent's condition and health care }\end{array}$ \\
\hline
\end{tabular}




\begin{tabular}{|c|c|c|c|c|c|}
\hline & & & & & $\begin{array}{l}\text { Providing opportunities for } \\
\text { adolescents to express opinions and } \\
\text { making informed decisions } \\
\text { Continuity in health personnel } \\
\text { Giving adolescents the option of being } \\
\text { seen by professionals without their } \\
\text { parents }\end{array}$ \\
\hline $\begin{array}{l}\text { Cramm, } \\
\text { Strating, } \\
\text { Sonneveld \& } \\
\text { Neiboer (2013) } \\
\text { The } \\
\text { Netherlands }\end{array}$ & $\begin{array}{l}\text { JIA \& } \\
\text { others }\end{array}$ & N/A & $\begin{array}{l}\text { To identify the relationship } \\
\text { between satisfaction with } \\
\text { transitional care and quality } \\
\text { of life }\end{array}$ & $\begin{array}{l}\text { QOL (DISABKIDS) }(\mathrm{V}) \\
\text { Satisfaction with transitional } \\
\text { care (Mind the Gap) }(\mathrm{V})\end{array}$ & $\begin{array}{l}\text { Analysis showed a significant link } \\
\text { between satisfaction with transitional } \\
\text { care at baseline (TO) and emotional } \\
\text { and physical QOL at } 1 \text { year (T1) later } \\
\text { both at } \leq 0.05 \text { ) } \\
\text { At } T 1 \text {, satisfaction with transitional } \\
\text { care was significantly related to the } \\
\text { emotional, physical, and social } \\
\text { domains of QOL (all at } \leq 0.001 \text { ) } \\
\text { Regression analysis showed that } \\
\text { satisfaction with transitional care at T1 } \\
\text { was related to emotional ( } p \leq 0.05 \text { ) and } \\
\text { social ( } p \leq 0.01 \text { ) quality of life domains } \\
\text { over time }\end{array}$ \\
\hline $\begin{array}{l}\text { Lawson et al } \\
\text { (2011) } \\
\text { USA }\end{array}$ & JIA \& others & & $\begin{array}{l}\text { Assess medication adherence } \\
\text { in patients transitioning }\end{array}$ & $\begin{array}{l}\text { Questionnaire measuring: } \\
\text { Disease self- management } \\
(\mathrm{NV}) \\
\text { Cognitive and emotional } \\
\text { representations of illness }\end{array}$ & $\begin{array}{l}\mathrm{N}=52 \\
54 \% \text { of participants reported } \\
\text { medication adherence. } \\
40 \% \text { reported } 1-2 \text { missed doses a } \\
\text { week. }\end{array}$ \\
\hline
\end{tabular}




\begin{tabular}{|c|c|c|c|c|c|}
\hline & & & & $\begin{array}{l}\text { (Brief Illness Perception } \\
\text { Questionnaire) }(\mathrm{V}) \\
\text { Self-care agency (Exercise of } \\
\text { Self-Care Agency) }(\mathrm{V}) \\
\text { Patient characteristics that } \\
\text { may mediate disease self- } \\
\text { management }\end{array}$ & $\begin{array}{l}6 \% \text { reported missing } 3 \text { doses or more. } \\
\text { The most common reason for missing } \\
\text { medication was forgetfulness. } \\
\text { There was an age-related increase in } \\
\text { the ability to fill in prescriptions, } \\
\text { schedule appointments, arrange } \\
\text { transportation, ask questions of } \\
\text { doctors, manage insurance and } \\
\text { recognise symptoms of illness. }\end{array}$ \\
\hline $\begin{array}{l}\text { McDonagh } \\
(2004) \\
\text { UK }\end{array}$ & JIA & $\mathrm{N} / \mathrm{A}$ & $\begin{array}{l}\text { To determine educational } \\
\text { needs of health professionals } \\
\text { and personnel }\end{array}$ & $\begin{array}{l}\text { Perceptions of Adolescent } \\
\text { Issues and Resources: Care } \\
\text { of Adolescents (NV) }\end{array}$ & $\begin{array}{l}\mathrm{N}=263 \text { (personnel, } \mathrm{n}=22 \text { ) } \\
\text { Education needs were reported by } \\
43 \% \text { of health professionals. } \\
\text { Transition issues ( } 23 \% \text { ) and } \\
\text { informational resources ( } 31 \% \text { ) were } \\
\text { the most frequently reported areas of } \\
\text { need } \\
\text { Personnel rated lack of training, lack of } \\
\text { teaching materials geared towards } \\
\text { adolescents, and limited clinical time } \\
\text { as main barriers to providing } \\
\text { developmentally appropriate care for } \\
\text { adolescents. }\end{array}$ \\
\hline $\begin{array}{l}\text { Sonneveld, } \\
\text { Strating, Van } \\
\text { Staa \& Nieboer } \\
\text { (2013) }\end{array}$ & JIA \& others & $\mathrm{N} / \mathrm{A}$ & $\begin{array}{l}\text { To explore the perspectives } \\
\text { of adolescents transitioning, } \\
\text { their parents and health care } \\
\text { providers }\end{array}$ & $\begin{array}{l}\text { Satisfaction with transitional } \\
\text { care (Mind the Gap) }(\mathrm{V})\end{array}$ & $\begin{array}{l}\text { Adolescents rate current care } \\
\text { significantly worse than parents on } \\
\text { two items: opportunities to make their } \\
\text { own decisions and being seen without } \\
\text { parents present }\end{array}$ \\
\hline
\end{tabular}




\begin{tabular}{|c|c|c|c|c|c|}
\hline $\begin{array}{l}\text { The } \\
\text { Netherlands }\end{array}$ & & & & $\begin{array}{l}\text { Provider Questionnaire: rate } \\
\text { a list of shortcomings in } \\
\text { transitional care }(\mathrm{NV})\end{array}$ & $\begin{array}{l}\text { Adolescents rate providers' current } \\
\text { social skills lower when compared to } \\
\text { the parent ratings } \\
\text { Adolescents are more satisfied than } \\
\text { their parents about transitional care } \\
\text { process aspects such as co-ordination } \\
\text { and communication between } \\
\text { providers, but both groups indicated } \\
\text { that the care process offers most } \\
\text { room for improvement } \\
\text { Providers report aspects such as } \\
\text { adolescents' lack of responsibility with } \\
\text { regard to self-care and parents' } \\
\text { difficultly with ceding control to their } \\
\text { children as barriers to transition }\end{array}$ \\
\hline $\begin{array}{l}\text { Shaw, } \\
\text { Watanabe, } \\
\text { Rankin \& } \\
\text { McDonagh } \\
\text { (2014) } \\
\text { UK }\end{array}$ & JIA & $\begin{array}{l}\text { Assess current } \\
\text { transitional } \\
\text { services }\end{array}$ & $\begin{array}{l}\text { Examine hospital adherence } \\
\text { to national transition } \\
\text { guidelines }\end{array}$ & $\begin{array}{l}\text { A clinic questionnaire to } \\
\text { assess transitional care } \\
\text { characteristics (NV) } \\
\text { Satisfaction survey (Mind } \\
\text { the Gap) (V) }\end{array}$ & $\begin{array}{l}\mathrm{N}=457 \text { (young people), } \mathrm{N}=330 \\
\text { (parents) } \\
14(70 \%) \text { of clinics reported having a } \\
\text { transition programme. Only } 5 \text { clinics } \\
(25 \%) \text { report holistic programmes } \\
\text { The ratings of current care were } \\
\text { significantly lower than ratings of best } \\
\text { care from both young people and } \\
\text { parents }(P<0.001) \\
\text { Parental satisfaction was higher for } \\
\text { those whose children attended a clinic } \\
\text { with a transitional programme }\end{array}$ \\
\hline
\end{tabular}




\begin{tabular}{|c|c|c|c|c|c|}
\hline & & & & & $\begin{array}{l}\text { compared with parents whose } \\
\text { children did not }(P<0.001) \\
\text { Increased satisfaction was associated } \\
\text { with attending holistic clinics for both } \\
\text { parents }(P<0.004) \text { and young people } \\
(P<0.009) \\
\text { There was increased satisfaction in } \\
\text { young people that attend clinics that } \\
\text { adhere to guidance compared to } \\
\text { clinics that do not JIA }(P=0.001)\end{array}$ \\
\hline $\begin{array}{l}\text { Jurasek, Quigly } \\
\text { \& Ray (2010) } \\
\text { Canada }\end{array}$ & Epilepsy & N/A & $\begin{array}{l}\text { An evaluation of an existing } \\
\text { transition programme }\end{array}$ & $\begin{array}{l}\text { Questionnaire to rate } \\
\text { statements regarding the } \\
\text { benefits of transitional clinic } \\
\text { (NV) }\end{array}$ & $\begin{array}{l}\mathrm{N}=78 \text { (adolescents), } \mathrm{N}=66 \\
\text { (caregivers) } \\
\text { All caregivers and adolescents agreed } \\
\text { or strongly agreed that the clinic was } \\
\text { beneficial } \\
97 \% \text { of female adolescents, all male } \\
\text { adolescents and } 95 \% \text { of caregivers } \\
\text { agreed or strongly agreed that the } \\
\text { transition appointment lessened fears } \\
\text { associated with moving to the adult } \\
\text { hospital } \\
\text { All adolescents and caregivers agreed } \\
\text { or strongly agreed that meeting the } \\
\text { nurse from the adult Epilepsy } \\
\text { programme was beneficial and } \\
\text { increased their knowledge of adult } \\
\text { issues }\end{array}$ \\
\hline
\end{tabular}




\begin{tabular}{|c|c|c|c|c|c|}
\hline & & & & & $\begin{array}{l}94 \% \text { of female adolescents, } 91 \% \text { of } \\
\text { male adolescents and } 95 \% \text { of } \\
\text { caregivers agreed or strongly agreed } \\
\text { that the differences between the } \\
\text { paediatric and adult programmes } \\
\text { were clear }\end{array}$ \\
\hline $\begin{array}{l}\text { Camfield \& } \\
\text { Camfield et al } \\
(2011) \\
\text { USA }\end{array}$ & Epilepsy & $\begin{array}{l}\text { Evaluation of } \\
\text { current } \\
\text { transitional } \\
\text { services }\end{array}$ & $\begin{array}{l}\text { To assess health care } \\
\text { providers' perspectives on } \\
\text { current issues and } \\
\text { characteristics of transitional } \\
\text { care }\end{array}$ & $\begin{array}{l}\text { Survey to assess the barriers } \\
\text { and facilitators to } \\
\text { transitional care (NV) }\end{array}$ & $\begin{array}{l}\mathrm{N}=133 \\
\text { Only } 13 \% \text { of respondents has used a } \\
\text { transition clinic } \\
30 \% \text { of respondents were 'not at all } \\
\text { satisfied' with their current method of } \\
\text { transition for their patients }\end{array}$ \\
\hline $\begin{array}{l}\text { Iyer \& } \\
\text { Appleton } \\
\text { (2013) } \\
\text { UK }\end{array}$ & Epilepsy & $\begin{array}{l}\text { Current } \\
\text { transitional } \\
\text { Epilepsy services } \\
\text { in the UK }\end{array}$ & $\begin{array}{l}\text { Survey current transitional } \\
\text { Epilepsy services in paediatric } \\
\text { neurology centres }\end{array}$ & $\begin{array}{l}\text { Survey to assess } \\
\text { characteristics of transition } \\
\text { clinics (NV) }\end{array}$ & $\begin{array}{l}18 \text { clinics participated } \\
\text { Most clinics were held between three } \\
\text { and twelve times per year (median = } \\
\text { 4) } \\
\text { Approximately } 3 \text { to } 5 \text { new, and } 3 \text { to } 8 \\
\text { follow up patients were seen in each } \\
\text { clinic } \\
\text { Most clinics accepted new referrals } \\
\text { with a minimum age of } 14 \text { and a } \\
\text { maximum age of } 20 \text { years } \\
47 \% \text { of clinics assessed new patients } \\
\text { only once in transition clinic before } \\
\text { moving to adult care }\end{array}$ \\
\hline
\end{tabular}




\begin{tabular}{|c|c|c|c|c|c|}
\hline & & & & & $\begin{array}{l}\text { The waiting time for new patients was } \\
\text { between } 1 \text { and } 12 \text { months (median = } 5 \\
\text { months) } \\
\text { Only } 20 \% \text { of clinics accepted direct } \\
\text { referrals from the GP } \\
33 \% \text { of clinics provided young people } \\
\text { and their families with written } \\
\text { information about the transition clinic } \\
\text { Adult teams provided more out-of- } \\
\text { hospital advice after the young person } \\
\text { was seen in the transition clinic ( } 53 \% \text { ) } \\
\text { compared to the paediatric team } \\
\text { (20\%) }\end{array}$ \\
\hline $\begin{array}{l}\text { Suris, Akre \& } \\
\text { Rutihauser } \\
\text { (2009) } \\
\text { Switzerland }\end{array}$ & Neurology & N/A & $\begin{array}{l}\text { To evaluate whether adult } \\
\text { specialists comply with the } \\
\text { basic principles for a } \\
\text { successful transition of } \\
\text { adolescents }\end{array}$ & $\begin{array}{l}\text { Questionnaire that assess } \\
\text { adult specialists' delivery of } \\
\text { transitional care (Content } \mathrm{V} \text { ) }\end{array}$ & $\begin{array}{l}\mathrm{N}=102 \\
54 \% \text { of physicians did not spend time } \\
\text { alone with their patients and sensitive } \\
\text { issues were not widely discussed. } \\
59 \% \text { of respondents did have an } \\
\text { established protocol } \\
54 \% \text { of respondents did not have } \\
\text { contact with a paediatric specialist }\end{array}$ \\
\hline $\begin{array}{l}\text { Chira, Ronis, } \\
\text { Ardoing \& } \\
\text { White (2014) } \\
\text { USA \& Canada }\end{array}$ & $\begin{array}{l}\text { Rheumatolog } \\
\text { y }\end{array}$ & $\begin{array}{l}\text { Assessing } \\
\text { current practice }\end{array}$ & $\begin{array}{l}\text { To assess paediatric } \\
\text { providers' perspectives on } \\
\text { practices, barriers, and } \\
\text { opportunities concerning the } \\
\text { transition from paediatric } \\
\text { care to adult care }\end{array}$ & $\begin{array}{l}\text { 25-item survey assessing } \\
\text { current transition practices } \\
\text { (NV) }\end{array}$ & $\begin{array}{l}\text { Fewer than } 10 \% \text { of providers were } \\
\text { very familiar with the American } \\
\text { Academy of Paediatricians (AAP) } \\
\text { guidelines }\end{array}$ \\
\hline
\end{tabular}




\begin{tabular}{|c|c|c|c|c|c|}
\hline & & & & & $\begin{array}{l}8 \% \text { had a formal written transition } \\
\text { policy but } 42 \% \text { use an informal } \\
\text { approach } \\
\text { Patient request usually initiated } \\
\text { transfer to adult care ( } 75 \%) \\
\text { Fragmented adult care and lack of } \\
\text { sufficient time to provide services } \\
\text { were noted as barriers to transition } \\
\text { Outcomes ranked as very important in } \\
\text { defining a successful transition were: } \\
\text { survival, seeing an adult } \\
\text { rheumatologist within } 6 \text { months of } \\
\text { final paediatric rheumatology visit and } \\
\text { maintaining insurance coverage. } \\
\text { Compared with AAP survey } \\
\text { participants, paediatric rheumatology } \\
\text { providers are more likely to help a } \\
\text { youth find an adult specialist, discuss } \\
\text { confidentiality and consent, but are } \\
\text { less likely to help with medical } \\
\text { summary creation or find a primary } \\
\text { care provider }\end{array}$ \\
\hline $\begin{array}{l}\text { Rutihauser, } \\
\text { Suris \& Akre } \\
\text { (2011) } \\
\text { Switzerland }\end{array}$ & Neurologists & $\mathrm{N} / \mathrm{A}$ & $\begin{array}{l}\text { Assess the expectations of } \\
\text { adolescents and their } \\
\text { parents' expectations about } \\
\text { transitioning to adult health } \\
\text { care }\end{array}$ & $\begin{array}{l}\text { 28-item cross-sectional } \\
\text { survey (NV) }\end{array}$ & $\begin{array}{l}\mathrm{N}=283 \text { (adolescents), } \mathrm{N}=318 \text { parents } \\
\text { completed the survey. } \\
50 \% \text { of adolescents and } 51 \% \text { of } \\
\text { parents perceived the best age to } \\
\text { transfer is } 18-19 \text { years of age }\end{array}$ \\
\hline
\end{tabular}




\begin{tabular}{|c|c|c|c|c|c|}
\hline & & & & & $\begin{array}{l}25 \% \text { of young people and } 35 \% \text { of } \\
\text { parents agreed that meeting both the } \\
\text { paediatric and adult specialist at a } \\
\text { paediatric hospital would be the most } \\
\text { suitable setting for meeting the adult } \\
\text { specialist for the first time } \\
\text { Chronological age and feeling too old } \\
\text { to see a paediatrician were reported } \\
\text { as the most important decision factors } \\
\text { for initiating transfer by patients (39\%) } \\
\text { and parents (34\%) } \\
\text { The most relevant barriers both } \\
\text { reported by young adults and parents } \\
\text { were; feeling at ease with the } \\
\text { paediatrician, anxiety and lack of } \\
\text { information about the adult specialist }\end{array}$ \\
\hline \multicolumn{6}{|c|}{ Studies assessing transitional care using audit/chart review measures } \\
\hline Author \& Year & Condition & $\begin{array}{l}\text { Transition } \\
\text { programme in } \\
\text { place }\end{array}$ & Rationale & Outcome Measures used & Results \\
\hline $\begin{array}{l}\text { Robertson, } \\
\text { McDonagh, } \\
\text { Southwood\& } \\
\text { Shaw (2006) } \\
\text { UK }\end{array}$ & JIA & $\begin{array}{l}\text { Transitional care } \\
\text { programme } \\
\text { (Growing up and } \\
\text { moving on } \\
\text { (McDonagh, } \\
\text { Southwood \& } \\
\text { Shaw) }\end{array}$ & $\begin{array}{l}\text { Assess the provisions for } \\
\text { transitional care to take }\end{array}$ & $\begin{array}{l}\text { Age when transition was } \\
\text { first discussed } \\
\text { When transfer occurred } \\
\text { Transitional care } \\
\text { components } \\
\text { Documentation of } \\
\text { transitional issues and } \\
\text { needs }\end{array}$ & $\begin{array}{l}\text { Increased documentation of parental } \\
\text { needs increased ( } 1.7 \% 26.7 \% \text {, } \\
p<0.001) \\
\text { Increased documentation of continuity } \\
\text { of senior medical staff }(58.4 \% \text { v } 87.1 \% \text {, } \\
p<0.001) \\
\text { Increased documentation of whether } \\
\text { an overlap visit to the paediatric clinic } \\
\text { was made after the first adult clinic }\end{array}$ \\
\hline
\end{tabular}




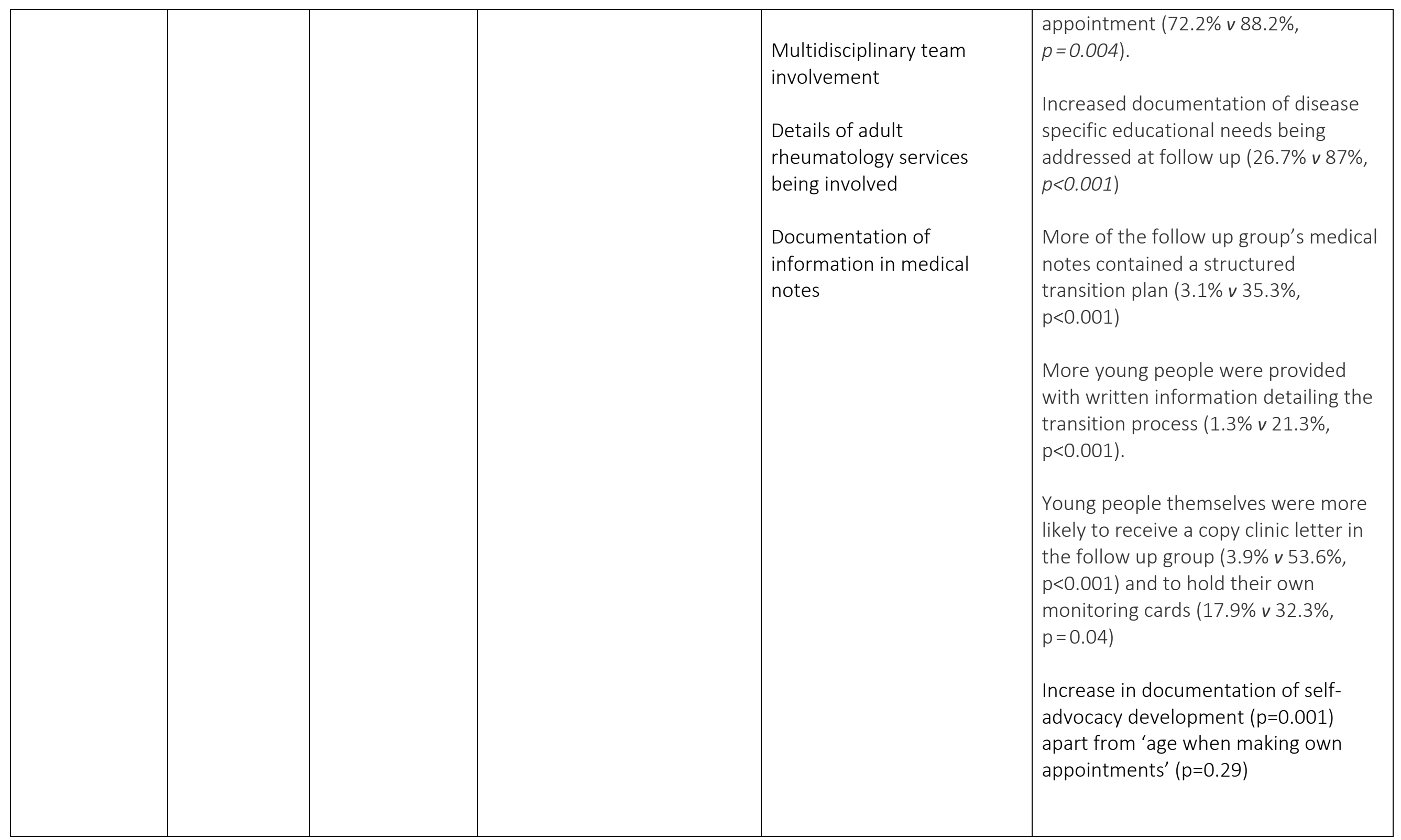




\begin{tabular}{|l|l|l|l|l|l|}
\hline $\begin{array}{l}\text { Hazel, Zhang, } \\
\text { Duffy \& } \\
\text { Campillo } \\
(2010)\end{array}$ & JIA & N/A & $\begin{array}{l}\text { To describe the proportion } \\
\text { and characteristics of patients } \\
\text { with JIA who have } \\
\text { experienced an unsuccessful } \\
\text { or successful transfer. }\end{array}$ & $\begin{array}{l}\text { Systematic chart review } \\
\text { (over two years) of patients } \\
\text { transferring to adult care }\end{array}$ & $\begin{array}{l}52 \% \text { of patients had an unsuccessful } \\
\text { transfer according to the criteria set } \\
\text { by the study. }\end{array}$ \\
& & $\begin{array}{l}\text { A low active joint count identified at } \\
\text { the last paediatric rheumatology clinic } \\
\text { was significantly associated with } \\
\text { unsuccessful transfer of care ( } p=0.08)\end{array}$ \\
\hline
\end{tabular}

V: validated; NV: non-validated; PAM: patient activation measure; VAS: visual analogue scale; QOL: quality of life; JAQQ: Juvenile Arthritis Quality of life Questionnaire; CHAQ: Childhood Health Assessment Questionnaire; COS: core outcome set; PEDSQL: Paediatric Quality of Life Inventor; SHCS-AQ: SWISS HIV Cohort Study Adherence Questionnaire; PI: Promotion Independence Scale; AAP: American Academy of Paediatricians; JIA: juvenile idiopathic arthritis. 
A total of 23 studies used outcome, audit or questionnaire measures to assess transitional care. Seven of these studies use mixed outcome measure designs including surveys, questionnaires and audits. Two of these studies use audit measures (Hazel et al., 2010; Robertson et al., 2006) and only one study used only validated outcome tools (Hilderson, 2015). The remaining studies used either a combination of validated and non-validated outcome measures, questionnaires and surveys to assess transitional care.

\section{Quality of life}

Four studies used quality of life $(\mathrm{QOL})$ measures to assess interventional or existing transitional care services (Cramm et al., 2013; Hilderson, 2016; McDonagh, Southwood et al., 2006; Stringer et al., 2015). One study evaluated the QOL in patients attending a paediatric transition clinic (Stringer et al., 2015) and another assessed the QOL of patients still under paediatric care who were yet to transition (Cramm et al., 2013). For those patients attending a transition clinic, impairments in all domains of QOL (including physical function, mental health and bodily pain) were found (using the Medical Outcomes Survey 36).

Two studies assessed QOL after implementation of a transition programme (Hilderson, 2015; McDonagh et al., 2006). McDonagh et al. (2006) measured whether QOL would increase when adolescents were exposed to an evidencebased programme of transitional care that was individualized to the patient; compared to baseline, significant improvements in QOL were reported for adolescent and parent-proxy ratings (Juvenile Arthritis Quality of life Questionnaire) at the 6- and 12-month follow-up. Hilderson et al. (2016) measured the impact of a brief transition programme on QOL at three time points: baseline, second outpatient visit to paediatric rheumatology and the 
first outpatient visit in adult rheumatology care. Although global QOL significantly improved overall, only a medium positive effect in improved psychosocial health and improved treatment modules were found (measured using the Paediatric Quality of Life Inventory).

\section{Satisfaction}

Six studies used satisfaction with transitional care as an outcome measure in their study. Two studies used non-validated measures (Disabato et al., 2015; Stringer et al., 2015). The remaining four used variations of Mind the Gap satisfaction survey before and after it was preliminary validated (Shaw et al., 2006). Shaw et al. (2006) found that satisfaction significantly increased for patients and their parents 12 months after entering a transition programme with an individualized approach to care and a local programme coordinator. Parent satisfaction improved for $70.4 \%$ of items measured; however, for adolescents, satisfaction only significantly improved for three items (has staff who are very knowledgeable about arthritis and the latest treatments, has staff who know how to talk and listen to teenagers and has a named member of staff who is responsible for co-ordinating my son/daughter's care). In addition, an evaluation of the same transition programme showed that satisfaction scores for adolescents and parents significantly improved at the 6-and 12-month follow-up, with no significant deterioration in between follow-ups. Using the Mind the Gap measure, Cramm et al. (2013) found that patient satisfaction with transitional care was significantly linked to emotional and physical QOL domains at baseline and follow-up (McDonagh, 2007). A questionnaire was implemented to these patients, parents and health-care provider to identify which areas of the transition programme had adequacy (McDonagh et al2006). The questionnaire found that adolescents had significantly higher scores of 
acceptability for the role of a local project coordinator compared to paperbased resources.

In a study using Mind the Gap to measure young people and their parents' satisfaction (Shaw et al., 2014), ratings of current care were significantly lower than ratings of best care from both young people and their parents. Increased significant satisfaction for young people and their parents was associated with attending clinics with a holistic approach. Furthermore, a significant increase in satisfaction was associated with attending a transition clinic that adhered to national guidance, compared to attending a clinic that did not adhere to proposed guidance. Interestingly, Chira et al. (2014) developed a survey for health-care providers that assessed current transitional services; it was found that only $10 \%$ of 158 providers were 'very' familiar with guidelines and only $8 \%$ had a formal written transition plan. In addition, Oskoui and Wolfson (2012) also showed that $75 \%$ of 119 providers reported not having a patient transition policy or programme in place. Moreover, Camfield and Camfield (2011) found that $30 \%$ of 133 health-care providers were 'not at all satisfied' with their current method of transitioning patients.

\section{Barriers and facilitators to transition}

Kuchenbuch et al. (2013) found that quality of transition preparation, longer duration of follow-up by the same child neurologist, the availability of child neurology staff, a transfer after the age of 18 and a stable medical condition before transition are significant factors that positively impact transfer for a patient. Similarly, in a two-stage Delphi survey, young people, parents and health providers all agreed that continuity in health personnel that constitutes best transitional care, including other items such as addressing young peoples' psychosocial, educational and vocational needs, having an individualized 
approach to transition, receiving honest explanations of the adolescent's condition and care, providing opportunities for adolescents to express opinions and make informed decisions and giving adolescents the option of being seen by professionals without their parents. Furthermore, Jurasek et al. (2010) found that the majority of adolescents and caregivers agreed that a transition appointment led to reduced fears about transferring to adult health services and, in addition, meeting the adult hospital nurse increased their knowledge about issues relating to moving to the adult hospital.

Barriers relating to successful transitional care were also found; yet, these mostly related to the perceptions of health-care providers, reporting a lack of critical information needed during transfer (Oskoui and Wolfson, 2012) and paucity of education and training needed to provide appropriate transitional care (McDonagh et al., 2004). Additionally, providers rated aspects such as adolescent's lack of responsibility in regard to their self-care and parent's ceding control to their children as prominent barriers to transition (Sonneveld et al., 2012). Furthermore, both adolescents and parents rated anxiety and a lack of information about the adult specialist as the most relevant barriers to transitioning to adult care (Rutihauser et al., 2011).

\section{Discussion}

This scoping review of the literature identified 31 papers using our search criteria (2001-2016) that used both quantitative and qualitative methodologies to assess transitional care and explore the perspectives of young adults with JIA or epilepsy, their parents or carers and health professionals on transitional care services. Predominantly, this review gives insight into which pre-existing outcome measures have been previously used to measure transitional care for a young adult with JIA or epilepsy. Furthermore, the synthesis of literature 
supports existing literature identifying the key processes considered central to a successful transition.

Findings from the qualitative and quantitative literature showed an array of barriers and facilitators of successful transitional care from the perspectives of health professionals, adolescents and their parents/carers. A prominent theme throughout the literature was the need for young adults to become empowered to self-manage their own condition independently and confidently. The notion of needing to support and increase adolescent's self-advocacy during this time is supported in the wider literature (Bell, 2007; Viner, 2008) with selfmanagement interventions for young adults with chronic conditions being used and evaluated increasingly (Bal et al., 2016; Crowley et al., 2011). However, there is an abundance of research that illustrates the lack of capacity from health-care services to provide the resources and education required to increase independence (Lotstein et al., 2009; Mclaughlin et al., 2008).

From the literature, there is an understanding from parents and carers that they have difficulty adjusting to their role of reduced responsibility (Schultz, 2013), and this is further supported in the broader transition literature (Reed-Knight et al., 2014; Wright et al., 2017). Furthermore, the need for support for parents during this changing role throughout transition has been recognized (Meah et al., 2009; Williams et al., 2007). The results support an understanding in the wider literature that parents believe a child's transition should not be sudden but a slow process that includes opportunities for the child to self-manage their own condition (Heath et al., 2017). Despite one study included in this review using an outcome measure to assess parental support of child autonomy and promotion of child independence (Hilderson et al., 2016), there is a need for 
more research to assess parental needs and evaluate whether they are barriers or facilitators to their child's transition (Olsson et al., 2003).

There was consistent evidence in the literature concerning which processes are expected to or which have been experienced that support a young adult's capability to transfer to adult care. Examples include preparation for transition from health professionals, receiving an individualized approach to care and having a transition-specific team (Cruikshank et al., 2016; Hilderson et al., 2013; Howland and Fisher, 2015; Jurasek et al., 2010; Lewis and Noyes, 2013; Rutihauser et al., 2011; Schultz, 2013; Shaw et al., 2004; Tuchman et al., 2008; Van Staa et al., 2011). These provisions of service that enable a young person to move to adult health care are also supported in existing literature, provision of adolescent and transition-specific education for health professionals (Blalock,1996; De Rosa, 1999).

This review indicates an increased effort to educate young adults with the knowledge and self-management skills to move to adult care confidently. Despite an effort to increase the capability of the patient to manage their own condition and move to adult care independently and confidently, there is a lack of measures to assess patient readiness. Although one study's (Van Staa et al., 2011) main outcome was patient's transition readiness, the measure was newly designed for the purpose of the study, was a single question and therefore had limited reliability. No studies included in this review used standardized measures to measure patient readiness, demonstrating the need for increased use of existing evidence-based readiness measures, in turn preventing young adults from transitioning before they are ready (Stinson et al., 2014; Zhang et al. 2014). 
A review of the quantitative literature showed an evident paucity of interventions or current clinical transition pathways in place as well as the limited amount of relevant validated outcomes to measure transitional care. Despite the existence of 'Mind the Gap' (Shaw et al., 2006), a validated outcome measure, as well as the enrolment and utilization of the 'Ready Steady Go' (Nagra et al., 2015) programme across the United Kingdom (not yet validated), there is still a lack of robust evaluation of models of transitional care that use validated and relevant outcomes and appropriate follow-ups periods. Furthermore, a recent Cochrane review where they found only four small existing Randomised Control Trials (RCT) was found to review transitional care models or pathways, further proving the need for more robust research (Campbell et al., 2016).

\section{Limitations}

This review was conducted only using epilepsy and JIA due to the intention that our next phases of research will be implemented in the rheumatology and neurology services at Alder Hey Children's Hospital and partnering adult hospitals. Although some of the papers included in this review include a sample of patients with other LTCs alongside JIA and epilepsy, we realize that by focussing on these two conditions, we have limited the scope of literature that could be reviewed. JIA and epilepsy transitional care research is limited in comparison to other conditions such as diabetes. In addition to this limitation, our search strategy meant that we may have excluded relevant non-English research studies.

Using scoping methodology, the papers identified were of generally poor design (a lack of homogeneity in the quantitative studies meant critical appraisal of 
study design using a validated assessment tool was not achievable). Of the 23 quantitative studies, 18 were non-experimental studies and mostly included self-report survey designs. There were no studies that attempted a randomized control design and follow-ups were a maximum of 12 months, illustrating a need for more research that assesses what outcomes such as patient satisfaction maintain beyond 12 months into adulthood. Nevertheless, it is important to remember the challenges of using robust methodology (e.g. randomized trials) in this area of research (McDonagh and Kelly, 2010). Several studies lacked evidence-based outcome measures and consequently developed their own measures with invalidated reliability. Due to the paucity of robust literature, we can make limited inferences from the studies included in this review.

\section{Future research}

This study is phase one of an overall project that aims to explore transitional care for young adults with long-term conditions. Further research will include assessing the experiences and expectations of transitional care from stakeholder perspectives (young adults, families, healthcare professionals and NHS commissioners) as well as establish which key outcomes can be used to measure transitional care.

\section{Conclusion}

Despite the wealth of literature concerning what aspects of transitional care are key to a successful transition for young people with JIA or epilepsy included in this review, there is a paucity of research evaluating the effectiveness of interventions to support young people moving to adult care. The lack of any published evidence-based models of transitional care for patients with epilepsy 
or JIA highlights the urgent need for service development. Inconsistency over outcome measures used across the studies illustrates the need to improve the quality of research in this field and demonstrates the need for a developed set of core outcomes to measure transition. Research needs to be undertaken to synthesize and form a consensus as to which processes are key to successful transitional care. Equally as important, there is a need to develop an agreement over which outcome measures should be used to reliably measure transition and determine whether transitional care can influence long-term medical, psychosocial and vocational outcomes.

\section{Declaration of Conflicting Interests}

The author(s) declared no potential conflicts of interest with respect to the research, authorship, and/or publication of this article.

\section{Funding}

The author(s) disclosed receipt of the following financial support for the research, authorship, and/or publication of this article: This work was supported by the National Institute for Health Research Collaboration for Leadership in Applied Health Research and Care North West Coast (NIHR CLAHRC NWC). The views expressed are those of the authors and not necessarily those of the NHS, NIHR or Department of Health. 
Appendix A

\section{Search Criteria}

Transition* OR transfer* AND adolescen* OR young adult OR teen* OR child*AND JIA OR juvenile idiopathic arthritis OR juvenile rheumatoid arthritis OR epilepsy

\section{References}

Bal, M. I., Sattoe, J. N. T., Roelofs, P. D. D. M., Bal, R., Van Staa, AL, Miedema, H. S. (2016). Exploring effectiveness and effective componenets of selfmanagement for young people with chronic physical conditions: A systematic review. Journal of Patient Education and Counseling. 99 (8), 1293-1309.

Bell, L. (2007). Adolescent dialysis patient transition to adult care: a crosssectional survey. Journal of Pediatric Nephrology. 22 (5), 720-726.

Blalock, G. (1996). Community transition teams as the foundation for transition services for youth with learning disabilities. Journal of Learning Disabilities. 29 (2).

Braun, V., Clarke, V. (2006). Using thematic analysis in psychology. Journal of 
Qualitative Research in Psychology, 3(2), 77-101.

Camfield, P., Camfield, C. (2011). Transition to adult care for children with chronic neurological disorders. Journal of the American Neurological Association and the Child Neurology Society. 69 (3), 437-444.

Chira, P., Ronis, T., Ardoin, S., White. (2014). Transitioning youth with rheumatic conditions: perspectives of pediatric rheumatology providers in the United States and Canada. Journal of Rheumatology. 41 (4), 768-779.

Campbell, F., Biggs, K., Aldiss, S. K., O'Neill P. M., Clowes, M., McDonagh, J., While, A., Gibson F. (2016). Transition of Care for Adolescents From Paediatric Services to Adult Health Services. Cochrane Database of Systematic Reviews. 4, Article number CD009794.

Cohen, J. (1960). A coefficient of agreement for nominal scales. Journal of Educational Psychological Measures. 20, 37-46.

Cramm, J. M., Strating, M. M. H., Sonneveld, H. M., Neiboer, A. P. (2013). The longitudinal relationship between satisfaction with transitional care and social and emotional quality of life among chronically ill adolescents. Journal of Applied Research and Quality of Life. 8, 481-491. 
Crowley, R., Wolfe, I., Lock, K., McKee, M. (2011). Improving the transition between paediatric and adult healthcare: a systematic review. Archives of Disease in Childhood. 96, 548-553

Cruikshank, M., Foster, H. E., Stewart, J., Davidson, J. E., Rapley, T. (2016). Transitional care in clinical networks for young people with juvenile idiopathic arthritis: current situation and challenged. Journal of Clinical Rheumatology. 35 (4), 893-899.

DeRosa C. (1999). Service utilization among homeless and runaway youth in Los Angeles, California: Rates and reasons. Journal of Adolescent Health. 24, 190200.

Care Quality Commission. (2014). From the pond into the sea: Children's transition to adult health services http://www.cqc.org.uk/content/teenagerscomplex-health-needs-lacksupport-they-approach-adulthood.

Department of Health (2004) National service framework for children, young people and maternity services. Available from: https://www.gov.uk/government/publications/national-service-frameworkchildren-young-people-and-maternity-services. [Accessed 24th June]. 
Department of Health/ Department for Education and Skills (2004). National Service Framework for Children, Young People and Maternity Services. London: DoH/DfES.

Department of Health \& Department for education and skills (2006) Transition: getting it right for young people. Available from:

http://webarchive.nationalarchives.gov.uk/20130123205838tf_/http://www.dh .gov.uk/en/Publicationsandstatistics/Publications/PublicationsPolicyAndGuidanc e/DH_4132145. [Accessed: $16^{\text {th }}$ June].

Department of Health \& Department for children schools and families (2007) A transition guide for all services. Available from: http://webarchive.nationalarchives.gov.uk/20120106114123tf_/https://www.e ducation.gov.uk/publications/standard/Integratedworking/Page1/DCSF-007762007. [Accessed $13^{\text {th }}$ June].

Department of Health \& Department for children schools and families (2008) Transition: moving on well. Available from: https://www.bacdis.org.uk/policy/documents/transition_moving-on-well.pdf. [Accessed $13^{\text {th }}$ June].

Disabato, J. A., Cook, P. F., Hutton, L., Dinkel, T., Levisohn, P. M. (2015). Transition from pediatric to adult speciality care for adolescents and young 
adults with refractory epilepsy: a quality improvement approach. Journal of Pediatric Nursing. 30 (5), 37-45.

Geerlings, R. P., Aldenkamp, A. P., Gottmer-Welschen, L. M., de With, P. H., Zinger, S., Van Staa, A. L., de Louw, A. J. (2016). Evaluation of a multidisciplinary epilepsy transition clinic for adolescents. European Journal of Paediatric Neurology. 20 (3), 385-392.

Hazel, E., Zhang, X., Duffy, C. M., Campillo, S. (2010). High rates of unsuccessful transfer to adult care among young adults with juvenile idiopathic arthritis. Journal of Pediatric Rheumatology. 8 (2).

Heath G, Farre A, Shaw K (2017) Parenting a child with chronic illness as they transition into adulthood: A systematic review and thematic synthesis of parents' experiences. Journal of Patient Education Counselling. 100(1), 76 -92 Hilderson, D., Eyckmans, L., Van der Elst, K., et al. (2013). Transfer from paediatric rheumatology to the adult rheumatology setting: experiences and expectations of young adults with juvenile idiopathic arthritis. Journal of Clinical Rheumatology. 32, 575-583.

Hilderson, D., Moons, P., Van Der Elst, K., Luyckx, K., Wouters, C., Westhovens, R. (2016). The clinical impact of a brief transition programme for young people 
with juvenile idiopathic arthritis: results of the DON'T RETARD project. Journal of Rheumatology. 55 (1), 133-142.

Howland, S., Fisher, K. (2015). Looking through the patient lens - Improving best practice for young people with juvenile idiopathic arthritis transitioning into adult care. SpringerPlus. 4, 111.

Iyer, A., Appleton, R. (2013). Transitional services for adolescents with epilepsy in the UK: A survey. Journal of Seizure. 22 (6), 433-437.

Jurasek, L., Ray., L., Quigly, D. (2010). Development and implementation of an adolescent epilepsy transition clinic. Journal of Neuroscience Nursing. 42 (4), 181-189.

Kennedy, A., Sloman, F., Douglass, A., Sawyer M. (2007) Young people with chronic illness: the approach to transition. Journal of Internal Medicine. 37 (8), 555-560.

Kuchenbuch, M., Chemaly, N., Chiron, C., Dulac, O., Nabbout, R. (2013). Transition and transfer from pediatric to adult health care in epilepsy: a families' survey on Dravet syndrome. Journal of Epilepsy and Behaviour. 29 (1), 161-165.

Lawson, E. F., O Hersh, A., Applebaum, M. A., Yelin, E. H., Okumura, M. J., Von Scheven, E. (2011). Self-management skills in adolescents with chronic 
rheumatic disease: A cross-sectional survey. Journal of Pediatric Rheumatology. 9, 35.

Lewis, S. A., Noyes, J. (2013). Effective process or dangerous precipice:

qualitative comparative embedded case study with young people with epilepsy and their parents during transition from children's to adult services. Journal of BMC Paediatrics. 13, 169

Lotstein, D. S., Ghandour, R., Cash, A., McGuire, E., Strickland, B., Newacheck, P. (2009). Planning for health care transitions: results from the 2005-2006 national survey of children with special health care needs. Journal of Pediatrics. 123 (1).

National Institute for Health and Care Excellence (NICE). (2016). Transition from children's to adults' services for young people using health and social care services. NICE guideline (NG43)

Meah, A., Callery, P., Milnes, L., Rogers, S. (2009). Thinking 'taller': sharing responsibility in the everyday lives of children with asthma. Journal of Clinical Nursing. 19 (13-14), 1952-1959.

McDonagh, J. E., Southwood, T. R., Shaw, K. L. (2004). Unmet education and training needs of rheumatology health professionals in adolescent health and transitional care. Journal of Rheumatology. 43 (1), 737-743. 
McDonagh, J. E., Shaw, K. L., Southwood, T. R. (2006). Growing up and moving on in rheumatology: development and preliminary evaluation of a transitional care programme for a multicentre cohort of adolescents with juvenile idiopathic arthritis. Journal of Child Health Care. 10 (1),

McDonagh, J. E., Southwood, T. R., Shaw, K. L. (2006). The impact of a coordinated transitional care programme on adolescents with juvenile idiopathic arthritis. Journal of Rheumatology. 47 (1), 161-168

McDonagh, J. E., Viner, R. M. (2006) Lost in transition? Between paediatric and adult services. British Medical Journal. 332 (7539), 435-436.

McDonagh, J. E., Kelly, D. A. (2010). The challenged and opportunities for transitional care research. Journal of the International Pediatric Transplant Association. 14 (6), 688-700.

McLaughlin, S. E., Diener-West, M., Imdurkhya, A., Rubin, H., Heckman, R., Boyle, M. P. (2008). Improving transition from pediatric to adult cystic fibrosis care: lessons from a national survey of current practices. Journal of Pediatrics. $121(5)$

Nagra, A., McGinnity, P. M., Davis, N., Salmon, A. P. (2015). Implementing Ready Steady Go. Archives of Disabled Children: Education and Practice. 100, 313-320. 
NHS Children's Review: Getting it right for children and young people. (2010). Available from: https://www.gov.uk/government/publications/getting-it-rightfor-children-and-young-people-overcoming-cultural-barriers-in-the-nhs-so-asto-meet-their-needs [Accessed $24^{\text {th }}$ June]

Olsson, C. A., Bond, L., Johnson, M. W., Forer, D. L., Boyce, M. F. and Sawyer, S. M. (2003). Adolescent chronic illness : a qualitative study of psychosocial adjustment. Annals of the Academy of Medicine Singapore. 32 (1), 43-50 Oskoui, M., Wolfson, C. (2012). Current practice and views of neurologists on the transition from pediatric to adult care. Journal of Child Neurology. 27 (12), 1553-1558.

Perrin, J. M., Van Cleave, J., Anderson, L.E. (2014). The rise in chronic conditions among infants, children, and youth can be met with continued health system innovations. Journal of Health Affairs. 33 (12), 2099-105.

Reed-Knight, B., Blount, R. L., Gilleland, J. (2014). The transition of health care responsibility from parents to youth diagnosed with chronic illness: a developmental systems perspective. Journal of Families, Systems, \& Health. 32 (2), 219-234.

Rosen, D. S., Blum, R. W., Britto, M., Sawyer, S. M., Siegel, D. M. (2003). Transition to adult health care for adolescents and young adults with chronic 
conditions: position paper of the Society for Adolescent Medicine. Journal of Adolescent Health. 33 (4), 309-311.

Royal College of Paediatrics and Child Health (2003) Bridging the gaps: health care for adolescents. Available from: www.rcpch.ac.uk [Accessed $24^{\text {th }}$ June] Robertson, L. P., McDonagh, J. E., Southwood, T. R., Shaw, K. L. (2006). Growing up and moving on. A multicentre UK audit of the transfer of adolescents with juvenile idiopathic arthritis from paediatric to adult centred care. Journal of Rheumatic Diseases. 65 (1).

Rutihauser, C., Akre, C., Suris, J-C. (2011). Transition from pediatric to adult health care: expectations of adolescents with chronic disorders and their parents. European Journal of Pediatrics. 170 (7), 865-871.

Shaw, K. L., Southwood, T. R., McDonagh, J. E. (2004). Transitional care for adolescents with juvenile idiopathic arthritis: a Delphi study. Journal of Rheumatology. 43 (8), 1000-1006.

Shaw, K. L., Southwood, T. R., McDonagh, J. E. (2004). Developing a programme of transitional care for adolescents with juvenile idiopathics arthritis: results of a postal survey. Journal of Rheumatology. 43 (2), 211-219 
Shaw, K. L., Southwood, T. R., McDonagh, J. E. (2006). Young people's satisfaction of transitional care in adolescent rheumatology in the UK. Journal of Child: Care, Health and Development. 33 (4), 368-379.

Singh, S. P., Paul, M., Ford, T., Kramer, T., Weaver, T., McLaren, S. Hovish, K., Islam, Z., Belling, R., White, S. (2010). Process, outcome and experience of transition from child to adult mental healthcare: multiperspective study. The British Journal of Psychiatry. 197 (4), 305-312.

Sonneveld, H. M., Strating, M. M. H., Van Staa, A. L., Nieboer, A. P. (2012). Gaps in transitional care: what are the perceptions of adolescents, parents and providers? Journal of Child: Care, Health and Development. 39 (2), 69-80.

Stringer, E., Scott, R., Mosher, D., MacNeill, I., Huber, A. M., Ramsey, S., Lang, B. (2015). Evaluation of a rheumatology transition clinic. Journal of Pediatric Rheumatology. 13, 22.

Suris, J-C., Akre, C., Rutihauser, C. (2009). How adult specialists deal with the principles of a successful transition. Journal of Adolescent Health. 46 (96), 551555.

Suris, J-C., Akre, C. (2015). Key elements for, and indicators of, a successful transition: An international delphi study. Journal of Adolescent Health. 56 (6), $612-618$ 
Tysbina, I., Kingnoth, S., Maxwell, J., Bayley, M., Lindsey S. (2012). Longitudinal Evaluation Transition Services ("LETS Study"): Protocol for outcome evaluation. Journal of BMC Pediatrics. 12, 51.

Shaw, K. L., Southwood, T. R., McDonagh J. E. (2004). User perspectives of transitional care for adolescents with juvenile idiopathic arthritis. Journal of Rheumatology. 43 (6), 770-778.

Shaw, K. L., Watanabe, A., Rankin, E., McDonagh, J. E. (2014). Walking the talk. Implementation of transitional guidance in a UK paediatric and a neighbouring adult facility. Journal of Child: Care, Health and Development. 40 (5), 663-670.

Schultz, R. J. (2013). Parental experiences transitioning their adolescent with epilepsy and cognitive impairments to adult health care. Journal of Paediatric Health Care. 27 (5), 359-366.

Stinson, J., Kohut, S. A., Spiegal, L., White, M., Gill, N., Colbourne, G., Sigurdson, S., Duffy, K. W., Tucker, L., Stringer, E., Hazel, B., Hochman, J., Resiss, J., Kaufman, M. (2014). A systematic review of transition readiness and transfer satisfaction measures for adolescents with chronic illness. International Journal of Adolescent Medical Health. 26 (2), 159-174. 
Tuchman, L. K., Slap, G. B., Britto, M.T. (2008). Transition to adult care:

experiences and expectations of adolescents with a chronic illness. Journal of Child Care Health Development. 34 (5), 557-563.

Van Staa, A. L., Jedeloo, S., Van Meeteren, J., Latour, J. M. (2011). Crossing the transition chasm: experiences and recommendations for improving transitional care of young adults, parents and providers. Journal of Child Health Development. 37 (6), 821-832.

Viner, R. M. (2008). Transition of care from paediatric to adult services: one part of improved health services for adolescents. Archives of Disease in Childhood. 93, 160-163.

Williams B., Mukhopadhyay S., Dowell J., Coyle J. (2007). From child to adult: An exploration of shifting family roles and responsibilities in managing physiotherapy for cystic fibrosis. Journal of Social Science \& Medicine. 65.

Wright, J., Elwell, L., McDonagh, J. E., Kelly, D. A., Wray, J. (2017). Parents in transition of young people with a liver transplant transferring to adult services. Journal of Pediatric Transplantation. 21.

Zhang, L. F., Ho, Jane, S. W., Kennedy, S. E. (2014). A systematic review of the psychometric properties of transition readiness assessment tools in adolescents with chronic disease. BMC Pediatrics. 14, 4. 
